\title{
Replication initiates at a confined region during DNA amplification in Sciara DNA puff II/9A
}

\author{
Chun Liang, Josephine D. Spitzer, ${ }^{1}$ Heidi S. Smith, and Susan A. Gerbi ${ }^{2}$ \\ Division of Biology and Medicine, Brown University, Providence, Rhode Island 02912 USA
}

Two independent two-dimensional (2D) gel methods were used to map an origin of replication that is developmentally regulated by the steroid hormone ecdysone, namely an origin for DNA puff amplification in the fungus fly Sciara coprophila. Initiation of replication was found to occur within a small region of no larger than $6 \mathrm{~kb}$ by use of the neutral/neutral 2D gel method. Neutral/alkaline 2D gel analyses support the results of the neutral/neutral $2 \mathrm{D}$ gels and further define within the origin region an $\sim 1-\mathrm{kb}$ area where the majority of replication initiates. This is the first example of an origin of replication in multicellular eukaryotes that has been mapped by 2D gels to such a small defined region. Moreover, replication can be seen by the neutral/alkaline 2D gel method to proceed bidirectionally outward from this replication origin region. These data are consistent with an onion-skin mechanism whereby multiple rounds of DNA replication initiate at a specific origin of replication for Sciara DNA puff amplification.

[Key Words: Replication origin; two-dimensional gels; DNA amplification; Sciara DNA puff]

Received February 18, 1993; accepted March 16, 1993.

DNA replication constitutes one of the most prominent phases and crucial points of control in the cell cycle. The mechanism and regulation of chromosomal DNA replication in eukaryotes, however, are poorly understood. Although the origins of replication of prokaryotes (Bramhill and Kornberg 1988), animal viruses (DePamphilis 1987; Challberg and Kelly 1989; Stillman 1989), and the yeast Saccharomyces cerevisiae (Walker et al. 1991; Deshpande and Newlon 1992; Marahrens and Stillman 1992; Rivier and Rine 1992) have been defined as specific structures and sequences, multicellular eukaryotic origins of replication have thus far not been defined.

Using two-dimensional (2D) gel electrophoresis methods to map replication origins in the yeast $S$. cerevisiae (Brewer and Fangman 1987; Huberman et al. 1987), the replication origin in the yeast $2 \mu$ plasmid was found to be at or near the autonomously replicating sequence (ARS) element. Some, but not all, ARS elements function as replication origins when they are chromosomally located (Hubberman et al. 1988; Linskens and Huberman 1988; Umek et al. 1989; Brewer and Fangman 1991; Dubey at al. 1991; Ferguson et al. 1991; Walker et al. 1991; Deshpande and Newlon 1992; Rivier and Rine 1992; Zhu et al. 1992). The neutral/neutral 2D gel method of Brewer and Fangman (1987) is useful to determine whether a DNA fragment contains a replication origin or is replicated by replication forks that traverse

${ }^{1}$ Present address: Pfizer, Inc., Central Research Division, Groton, CT 06340.

${ }^{2}$ Corresponding author. the fragment. The neutral/alkaline 2D gel method of Huberman et al. (1987) can determine in addition the direction of replication fork movement, as can a recent modification of neutral/neutral 2D gels (Fangman and Brewer 1991).

As successful as the 2D gel methods were in describing replication origins in yeast as well as in a slime mold (Benard and Pierron 1992), animal viruses (Gahn and Schildkraut 1989; Schvartzman et al. 1990; Yang and Botchan 1990), and a plasmid (Martin-Parras et al. 1991), however, 2D gel mapping has failed so far to reveal discrete initiation sites in metazoans. To study this problem in metazoans, model systems of DNA amplification have been employed because they increase the number of replication intermediates from a particular locus, thereby strengthening the signal.

The amplified system studied most highly in mammals is the dihydrofolate reductase (DHFR) locus in Chinese hamster ovary cells. Replication origins detected by 2D gels seem to span as much as $55 \mathrm{~kb}$ of DNA in the 240-kb repeated amplicons (Vaughn et al. 1990; Dijkwel and Hamlin 1992). In contrast, other replicon mapping techniques suggest a more localized initiation region (for review, see DePamphilis 1993a,b|, and it was even possible to map an origin in this locus to $450 \mathrm{bp}$ by use of the Okazaki' fragment distribution method (Burhans et al. 1990). This apparent contradiction has not been resolved (for discussion of this paradox, see Linskens and Huberman 1990a; Fangman and Brewer 1992; DePamphilis 1993a,b). 
In contrast to DHFR amplification, which is selected by methotrexate in vitro, there are only two known cases of intrachromosomal DNA amplification that occur as normal events during development: amplification of the chorion gene loci of Drosophila and of the DNA puff loci in Sciarid flies. DNA amplification at one of the two chorion gene loci in Drosophila has been studied using the neutral/neutral 2D gel method (Delidakis and Kafatos 1989; Heck and Spradling 1990). Their data suggested multiple initiation sites spanning at least $12 \mathrm{~kb}$ in the region of the chorion gene transcription units (Heck and Spradling 1990). Replication bubbles are seen most easily in a central area of a few kilobases (Delidakis and Kafatos 1989), and data of discontinuous forks, whose significance is not established, have suggested a model for a preferred initiation site within the zone (Heck and Spradling 1990/. In another 2D gel study, the histone gene repeats and a single-copy locus of Drosophila early embryos were also found to initiate replication randomly (Shinomiya and Sawako 1991).

The first reported example of DNA amplification is in Sciarid DNA puffs, which occur during late larval development at specific loci on salivary gland polytene chromosomes (Breuer and Pavan 1955; Ficq and Pavan 1957; Gabrusewycz-Garcia 1964). Unlike RNA puffs in Drosophila, DNA puffs in the fungus fly, Sciara coprophila, not only are sites of active transcription (GabrusewyczGarcia and Kleinfeld 1966), but also of DNA amplification (Crouse and Keyl 1968; Rasch 1970a). Whereas the developmental cues that trigger chorion gene amplification and transcription in Drosophila are unknown, cytological puffing and the molecular events of DNA amplification and transcription in Sciarid DNA puffs are controlled by the insect steroid molting hormone, ecdysone (Crouse 1968; Bienz-Tadmor et al. 1991; C. Liang, N. $\mathrm{Wu}, \mathrm{D}$. Alam, H.S. Smith, and S.A. Gerbi, unpubl.). Therefore, the DNA puffs provide an attractive opportunity to study hormonal regulation of DNA amplification and transcription and the cross-talk in both processes.

With both temporally and spatially regulated DNA amplification, Sciarid DNA puffs offer an excellent model system to study DNA replication. Analysis is facilitated by the small genome size of Sciara (183 Megabases per haploid female genome, similar to Drosophila; Rasch 1970b) and the increased copy number of amplified DNA. Moreover, the slow rate of replication (Cordeiro and Meneghini 1973) during DNA amplification of DNA puff loci provides a greater abundance of replication intermediates. Additionally, DNA amplification is a normal part of the Sciara life cycle, so no artificial manipulation of the model system is required.

This paper describes a thorough analysis of a replication origin from Sciara DNA puff II/9A /locus 9A on chromosome II) by use of both the neutral/neutral and the neutral/alkaline $2 \mathrm{D}$ gel methods. Puff II/9A is the largest of the DNA puffs, contains two genes (II/9-1 and II/9-2) with $85 \%$ sequence similarity to each other that encode secretory polypeptides (DiBartolomeis and Gerbi 1989 ) and is amplified almost 20 -fold (Wu et al. 1993) This is the first time that $2 \mathrm{D}$ gels have been used suc- cessfully to map a replication origin in a multicellular eukaryote to a small region of no larger than $6 \mathrm{~kb}$ containing an $\sim 1-\mathrm{kb}$ area where the majority of DNA replication initiates. Furthermore, replication is seen to proceed bidirectionally outward from this defined replication origin region.

\section{Results \\ Initiation of replication is confined to a small region of DNA puff $I I / 9 A$}

A cosmid clone (cII/9) with a $35-\mathrm{kb}$ insert from the DNA puff II/9A locus was obtained from a genomic library of S. coprophila by use of cDNA from gene II/9-1 (DiBartolomeis and Gerbi 1989) as a probe. This clone was mapped by double digestions with restriction enzymes. Genes II/9-1 and II/9-2 are located near the center of the cII/9 clone (see map in Fig. 1). DNA fragments from subclones of cII/9 and from a $14.7-\mathrm{kb}$ insert in a $\lambda$ clone ( $\lambda$ pSDII/9; DiBartolomeis and Gerbi 1989) that covers some of the internal region of cII/9 were used as hybridization probes in $2 \mathrm{D}$ gel analysis.

The strategy of the neutral/neutral 2D gel of Brewer and Fangman (1987) is to separate different kinds of replication intermediates from each other and from nonreplicating linear DNA. Digested DNA is run in the first dimension of a low percentage agarose gel at a low voltage so that DNA molecules are resolved primarily by mass. The second dimension is a higher percentage agarose gel run at a high voltage so that DNA molecules are separated according to shape as well as mass. Therefore, different types of intermediates of replication land of recombination) produce different patterns. Four major arcs-fork, double fork, bubble and crossover-are depicted in the inset in Figure 1. When a blot of the 2D gel is probed for a restriction fragment, the pattern obtained will tell if the fragment contains an origin of replication (bubble arc) or is replicated by passing forks (fork and double fork arcs), or both.

EcoRI-digested total genomic DNA from puff stage salivary glands undergoing DNA amplification was run on a neutral/neutral $2 \mathrm{D}$ gel and probed sequentially with DNA fragments from each of the restriction fragments (probe a from the $9.0-\mathrm{kb}$ fragment, probe $\mathrm{b}$ from the 5.5$\mathrm{kb}$ fragment, etc.; Fig. 1, top). The 5.5-kb EcoRI fragment showed a bubble arc (Fig. 1b, open arrowhead) in addition to a fork arc, whereas fork but no bubble arcs were observed in the 9.0-, 3.5- and 9.5-kb EcoRI fragments (Fig. $1 \mathrm{a}, \mathrm{c}, \mathrm{d})$. This suggests that a replication origin(s) is within the 5.5-kb EcoRI fragment, and the other fragments are replicated by passing forks. Each set of hybridizations per restriction digestion were done sequentially on one filter to control for variations in the experimental conditions in all of the neutral/neutral and neutral/alkaline 2D gels in this study. Additional experiments indicated that a $4.7-\mathrm{kb}$ fragment located $1.2 \mathrm{~kb}$ downstream of the $9.5-\mathrm{kb}$ EcoRI fragment is also replicated by passing forks (data not shown). 


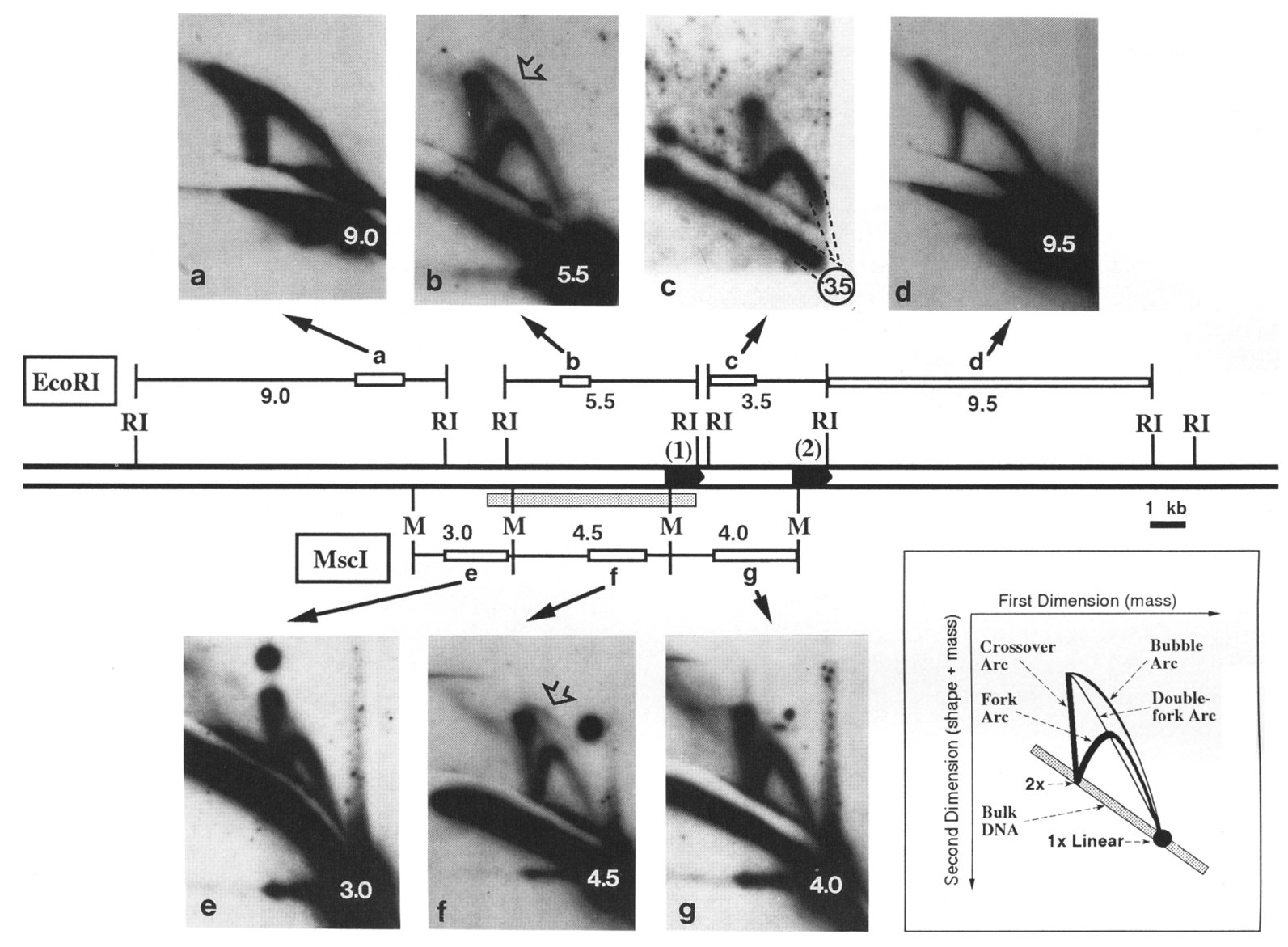

Figure 1. The initiation of replication is contained in a small region at the DNA puff II/9A locus. About $6 \mu \mathrm{g}$ of EcoRI /RI; top/- or of $\mathrm{MscI}\left(\mathrm{M}_{;}\right.$bottom)-digested total salivary gland genomic DNA was run on a neutral/neutral $2 \mathrm{D}$ gel and hybridized sequentially with various probes (open boxes; $a-d$ for $E c o$ RI; $e-g$ for $M s c I$; the fragment letter corresponds to each panel) from DNA puff II/9A. (Inset) Different patterns of neutral/neutral 2D gels are diagramed. The probes for the $5.5-\mathrm{kb} E c o \mathrm{RI}(b)$ and $4.5-\mathrm{kb} M s c I$ fragments $(f)$ hybridized to bubble arcs (open arrow) as well as to fork arcs. All other probes did not detect bubble arcs. The origin region of 6-kb maximum extent is shown by the stippled box (see text). A strong crossover arc and a weak double fork arc are present in all panels (see text for discussion). (1 and 2) Genes II/9-1 and II/9-2, with the solid arrowheads indicating the direction of transcription from 5' to $3^{\prime}$. The $1 \times$ spots of the linear restriction fragments are denoted by their sizes (in kilobases; white numbers). The $1 \times$ spot of the 3.5 -kb EcoRI fragment $(c)$ was run out of the gel. The round spot in $e$ and $f$ above the arcs is an artifact of the filter. Electrophoresis conditions for the EcoRI experiment were as follows: The first dimension was a $0.3 \%$ gel run at $0.75 \mathrm{~V} / \mathrm{cm}$ for $46 \mathrm{hr}$, the second dimension was a $0.75 \%$ gel run at $2.5 \mathrm{~V} / \mathrm{cm}$ for $17 \mathrm{hr}$. For the $\mathrm{MscI}$ experiment, a $0.35 \%$ gel was run at $0.9 \mathrm{~V} / \mathrm{cm}$ for $28 \mathrm{hr}$ in the first dimension, and a $1 \%$ gel was run at $3 \mathrm{~V} / \mathrm{cm}$ for $14 \mathrm{hr}$ in the second dimension. Upon UV visualization, the gels were sliced diagonally just above the bulk linear DNA, separated by $\sim 1 \mathrm{~cm}$, and blotted to avoid overexposure of the bulk DNA obscuring the replication intermediate signals.

That the initiation of replication is contained in a small region defined by the neutral/neutral $2 \mathrm{D}$ gel of EcoRI-digested DNA is supported by a neutral/neutral 2D gel of $M s c I$-digested DNA (Fig. 1, bottom). The $4.5-\mathrm{kb}$ MscI fragment, which aligns within the $5.5-\mathrm{kb}$ EcoRI fragment, produced both fork and bubble arcs (Fig. 1f) whereas the upstream and downstream neighboring fragments gave fork but no bubble arcs (Fig. le,g).

A strong crossover arc and a weaker double fork arc (see Fig. 1, inset) were seen in all of the neutral/neutral 2D gels (Fig. 1; also see Fig. 2). The double fork arcs, however, varied in intensity among different DNA preparations and digestions (Figs. 1 and 2; data not shown). Furthermore, when BND-cellulose chromatography was used to enrich replication intermediates on the basis of their partial single-strandedness, both crossover and double fork arcs were almost completely partitioned to the salt wash fraction (data not shown) that contains primarily double-stranded DNA. Therefore, the double fork arc, as well as the crossover arc, likely comes from predominantly double-stranded DNA structures, which probably result from branch migration of replication intermediates and/or recombination events rather than from replication directly.

The unlikely possibility that the failure to detect bubble arcs in fragments other than the 5.5-kb EcoRI and the 4.5-kb MscI fragments is the result of loss of DNA from the stripped filters can be ruled out. First, the probe for 


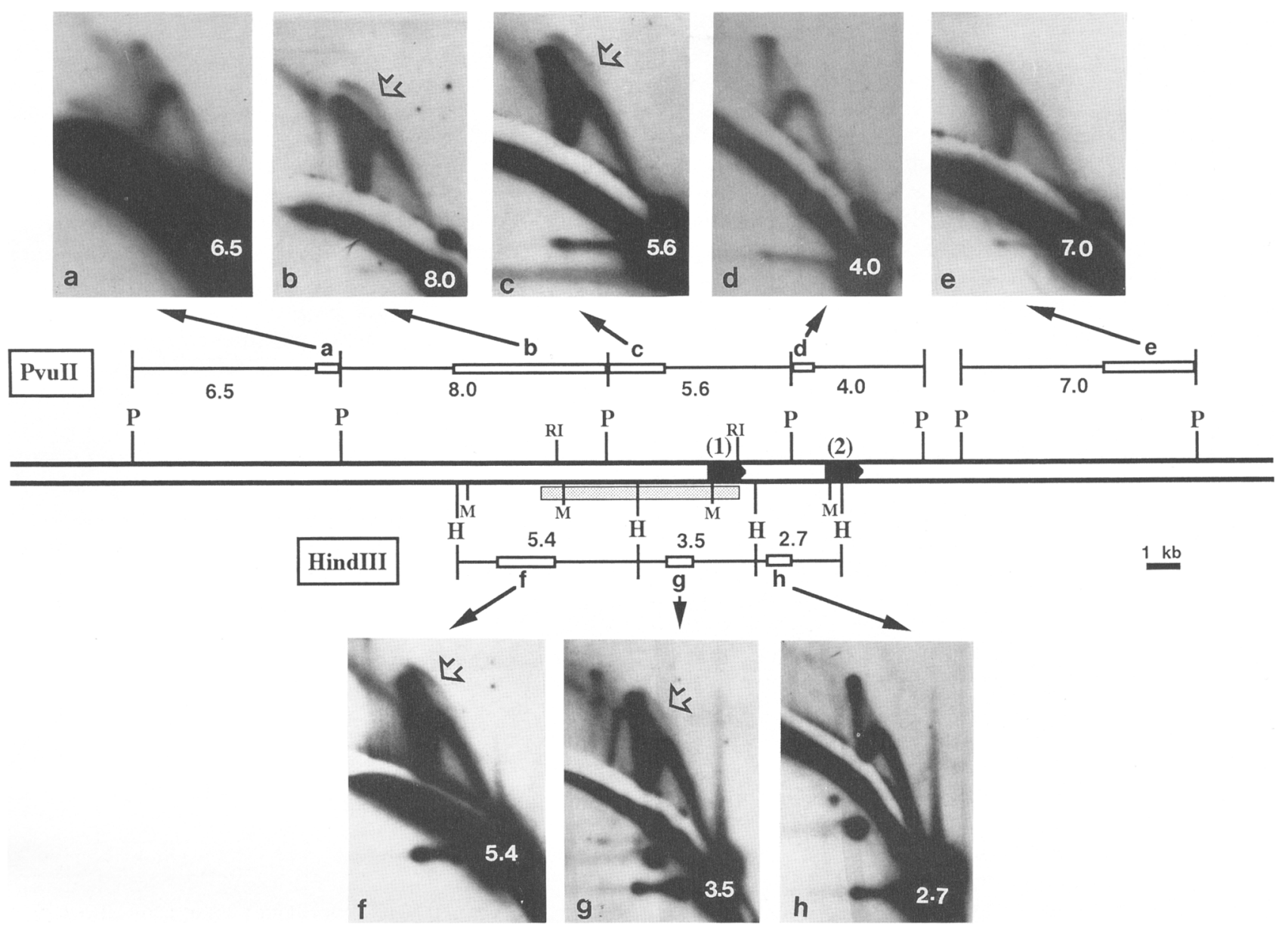

Figure 2. There seem to be multiple initiation sites within the origin region. About $10 \mu \mathrm{g}$ of PvuII $\{\mathrm{P}$; top $)$ - or of HindIII $(\mathrm{H}$; bottom)-digested salivary gland genomic DNA was run out on a neutral/neutral $2 \mathrm{D}$ gel and hybridized sequentially with various probes $(a-e$ for PvuII; $f-h$ for HindIII). A bubble arc (open arrow) in addition to a fork arc can be seen in the 8.0-kb $(b)$ and 5.6-kb $(c)$ $P$ vuII and the 5.4-kb $(f)$ and $3.5-\mathrm{kb}(\mathrm{g})$ HindIII fragments, suggesting multiple (at least two) initiation sites in the origin region. The origin region of 6-kb maximum extent (stippled box) and the relevant EcoRI and MscI sites are shown on the map. The fork and crossover arcs with higher mass in $g$ are attributable to incomplete digestion. Conditions for the PvuII experiment were similar to those of EcoRI-digested DNA (Fig. 1), except that the gel was run for a slightly shorter time in both dimensions. The HindIII experiment was done under similar conditions to MscI-digested DNA (Fig. 1).

either the 5.5-kb EcoRI or the 4.5-kb MscI fragment was not used in the first of the sequential hybridizations of each of the filters. Second, the 4.5-kb MscI fragment showed the same pattern (fork plus bubble arcs) when hybridized again after all other sequential hybridizations and strippings had been done (the last hybridization is shown in Fig. 1f). Finally, clearly visible bubble arcs were seen even in much shorter exposures (about one-fourth of the exposure time used in Fig. 1) for the 5.5-kb EcoRI and the $4.5-\mathrm{kb} M s c I$ fragments, whereas no bubble arcs were observed in other fragments even after prolonged exposure (data not shown).

The neutral/neutral 2D gel of MscI-digested DNA /Fig. 1 , bottom/ suggests that initiation is confined to the 4.5$\mathrm{kb} M s c I$ fragment, because the neighboring 3.0- and 4.0$\mathrm{kb} M s c I$ fragments do not contain bubble arcs. A bubble arc, however, may not be detected when the initiation site is located less than $\sim 20 \%$ of the fragment length from the end (Linskens and Huberman 1990b; Yang and Botchan 1990; Dubey et al. 1991). Therefore, the origin region may include at its maximum extent the entire $4.5-\mathrm{kb}$ MscI fragment, plus $20 \%$ of the surrounding fragments $(0.6$ and $0.8 \mathrm{~kb}$ from the 3.0- and the $4.0-\mathrm{kb} \mathrm{MscI}$ fragments, respectively), which sums up to $6-\mathrm{kb}$ (shown by the stippled rectangle in Fig. 1 and those following).

There seem to be multiple initiation sites within the origin region

The presence of a fork arc in addition to a bubble arc in the 5.5-kb EcoRI (Fig. $1 \mathrm{~b}$ ) and the 4.5-kb MscI (Fig. 1f) fragments suggests that there may be multiple initiation sites within the origin region. Alternatively, the fork 
arcs could come from replication emanating outside this region. The latter possibility can be ruled out by neutral/ alkaline 2D gel analysis of the direction of replication fork movement, which shows that forks move outward from the origin region in a bidirectional manner (see below). A third possibility, that bubbles break into forks thus giving rise to a fork arc (Ferguson et al. 1991), cannot be tested directly by either of the 2D gel methods.

There are unique restriction sites for both PvuII and HindIII within the $4.5-\mathrm{kb} M s c I$ fragment. A singular origin should result in only one of the two fragments flanking the unique PvuII site or HindIII site containing a bubble arc in neutral/neutral 2D gels. Both of the fragments formed by the respective PvuII or HindIII digestion, however, showed bubble plus fork patterns (Fig. $2 b, c$ and $f, g$, respectively) suggesting multiple (at least two) initiation sites within the origin region. As will be discussed later, however, the bubble arcs in Figure $2 \mathrm{~b}$ plus $\mathrm{c}$ and $\mathrm{f}$ plus $\mathrm{g}$, likely result from minor rather than major initiation events. As in the EcoRI and MscI experiments, PvuII or HindIII fragments outside the origin region gave fork but no bubble arcs (Fig. 2a,d,e, and h), consistent with the initiation of replication being limited to the origin region. The HindIII fragment upstream of the $5.4-\mathrm{kb}$ HindIII fragment is too large $(\sim 16 \mathrm{~kb})$ to be analyzed on the same filter used in Figure 2, although no bubble arc is expected because neither the 9.0-kb EcoRI fragment (Fig. la) nor the 6.5-kb PvuII fragment (Fig. 2a) produced a bubble arc.

Notice that the $8.0-\mathrm{kb}$ Pvull fragment contains only 2 $\mathrm{kb}$ of the 6-kb maximum origin region (see map in Fig. 2). Therefore, the bubbles in the $8.0-\mathrm{kb}$ PvuII fragment are no more than $50 \%$ replicated assuming bidirectional replication, although the bubble arc extends beyond the inflection point (50\% replication) of the fork arc (Fig. $2 \mathrm{~b}$ ). This phenomenon is also seen in neutral/neutral 2D gels in other systems (Brewer and Fangman 1987, 1991; Yang and Botchan 1990; Ferguson et al. 1991; Deshpande and Newlon 1992). A bubble, especially a large one, probably migrates more slowly than a fork of the same mass even under the low percentage gel and low voltage conditions of the first dimension in the $2 \mathrm{D}$ gel method.

\section{Replication proceeds bidirectionally outward from the origin region}

If replication is bidirectional, replication forks should move away from the origin region. This was found to be the case when the direction of fork movement in fragments upstream and downstream of the origin region were analyzed using the neutral/alkaline 2D gel method.

The first dimension of the neutral/alkaline 2D gel of Huberman et al. (1987) is the same as the neutral/neutral 2D gel of Brewer and Fangman (1987), separating DNA molecules primarily by mass. The second dimension is a $1.2 \%$ agarose gel run under alkaline conditions so that DNA molecules migrate as single strands. For example, a replication fork will be separated into two parental and two nascent strands. The parental strands from forks that have passed to varying extents through a given restriction fragment have the same length and migrate to the same position in the second dimension to give a horizontal line, whereas the nascent strands of these forks will form a diagonal arc because of the difference in their lengths (Fig. 3). The smallest nascent strands will migrate the fastest and be at the bottom of the diagonal, and the largest nascent strands will be at the top of the diagonal where it intercepts the line of the parental strands. If short pieces of DNA from different areas of the restriction fragment are used to probe a filter blot of the gel, the direction of fork movement can be deduced. When the probe is from the end where forks enter the fragment, small as well as large nascent strands will be detected and a complete nascent strand diagonal will be seen (Fig. 3a). If the probe is from the opposite end, only very large nascent strands will be detected and only the top portion of the nascent strand signal will be seen (Fig. $3 \mathrm{~b})$. If there is initiation of replication internal to the restriction fragment, a probe near the origin will detect

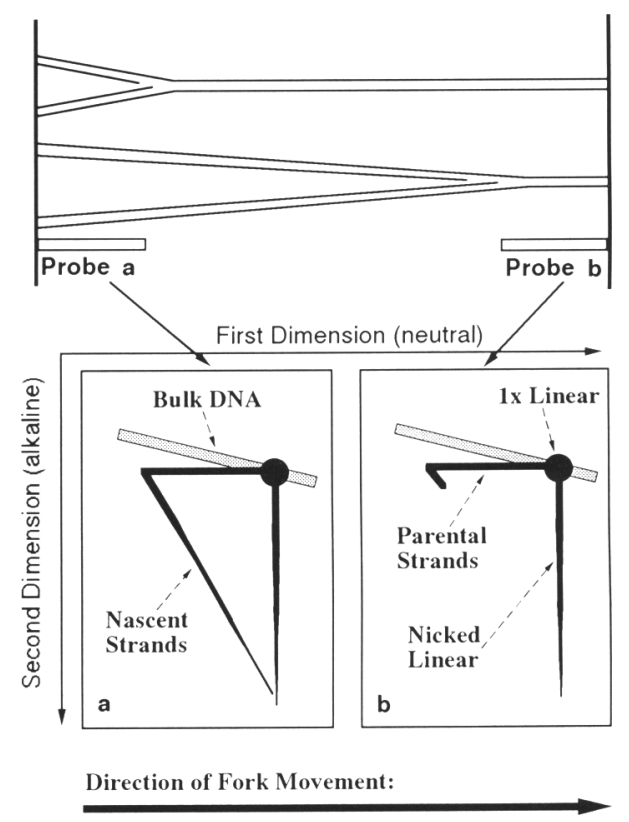

Figure 3. Schematic of the neutral/alkaline $2 \mathrm{D}$ gel method. (Top) The two forks are representatives from the collection of replication forks moving from left to right through a restriction fragment. After a neutral/alkaline $2 \mathrm{D}$ gel separation, the blot is sequentially hybridized with short probes (e.g., $a$ and $b$; open boxes) from the restriction fragment. (Bottom) Bulk DNA (stippled bar) is the background hybridization signal by the probes. The round spot $(1 \times$ linear $)$ is the hybridization signal of the intact nonreplicating restriction fragment. Nicked linear (vertical streak downward from $1 \times$ linear) is the result of random nicks in the linear fragment. Parental strands (horizontal line leftward from $1 \times$ linear) and Nascent strands (diagonal line; long in $a$ and short in $b$ ) are the hybridization signals of the parental and nascent strands, respectively, of the replication forks. The direction of fork movement (large arrow; bottom) can be deduced from the nascent strand signals in $a$ (all sizes) and $b$ (only large sizes). 
nascent strands of all sizes to give a complete nascent strand diagonal.

EcoRI-digested salivary gland DNA was enriched for replication intermediates by BND-cellulose chromatography and run on a neutral/alkaline $2 \mathrm{D}$ gel (Fig. 4). Probes $\mathrm{a}$ and $\mathrm{b}$ are from different areas of the $9.0-\mathrm{kb}$ $E c o R I$ fragment that maps upstream of the origin region. When the blot was sequentially hybridized with each probe, the direction of replication fork movement could be deduced by the sizes of nascent strands that were detected. Probe $\mathrm{b}$ at the right end of the fragment detected nascent strands of all sizes (the smallest nascent strands seen were $\sim 0.5 \mathrm{~kb}$, marked by the open triangle), whereas probe $\mathrm{a}$, whose right border is $4.5 \mathrm{~kb}$ from the right end and whose left border is $3.7 \mathrm{~kb}$ from the left end of the fragment, hybridized only to nascent strands $>4.5$ $\mathrm{kb}$, indicating that forks are moving from right to left. In contrast, forks in the $3.5-\mathrm{kb}$ EcoRI fragment downstream of the origin region were seen to move from left to right, because probe $\mathrm{c}$, whose left border is $1.3 \mathrm{~kb}$ from the left end of the fragment, hybridized to as small as $1.3-\mathrm{kb}$ nascent strands, and probe $d$ at the right end of the fragment hybridized to only very large nascent strands. Similarly, forks were also found to move from left to right in the 9.5-kb EcoRI fragment, which is immediately downstream of the $3.5-\mathrm{kb} E$ EcoRI fragment, by a probe located $1.8 \mathrm{~kb}$ from the left end of the fragment and a probe at the right end of the fragment (data not shown).

These data support the location of the origin region mapped by the neutral/neutral 2D gels (Fig. 1) and indi- cate that replication proceeds in a bidirectional manner outward from the origin region.

\section{Neutral/alkaline 2D gel analysis also shows initiation of replication within the origin region}

The neutral/alkaline 2D gel method can also detect the presence of bubbles, as well as the direction of replication fork movement, in a fragment. In the origin region, short probes internal to the $5.5-\mathrm{kb}$ EcoRI fragment should detect nascent strands of all sizes. This was tested by use of five short probes from the $5.5-\mathrm{kb} E c o R I$ fragment to sequentially hybridize the same blot used in Figure 4 of the neutral/alkaline 2D gel of EcoRI-digested DNA that was BND-cellulose enriched for replication intermediates. As a control for the specificity of these probes, a dot blot of short DNA fragments covering the entire 5.5-kb EcoRI fragment was included in each 2D gel hybridization, and no significant cross-hybridization of each probe to another area in the 5.5-kb EcoRI fragment was found (data not shown). As shown in Figure 5, each of the probes detected nascent strands of almost all sizes (open triangles), suggesting multiple initiation sites in the origin region.

The distances between the left end of the 5.5-kb EcoRI fragment and the left border of probes $b$ and $c$ are 1.6 and $2.8 \mathrm{~kb}$, respectively. Therefore, the nascent strand signals below the solid triangle marking $1.6 \mathrm{~kb}$ (probe b) or $2.8 \mathrm{~kb}$ (probe c) can only come from replication bubbles initiated at the vicinity of probe b or c, respectively,

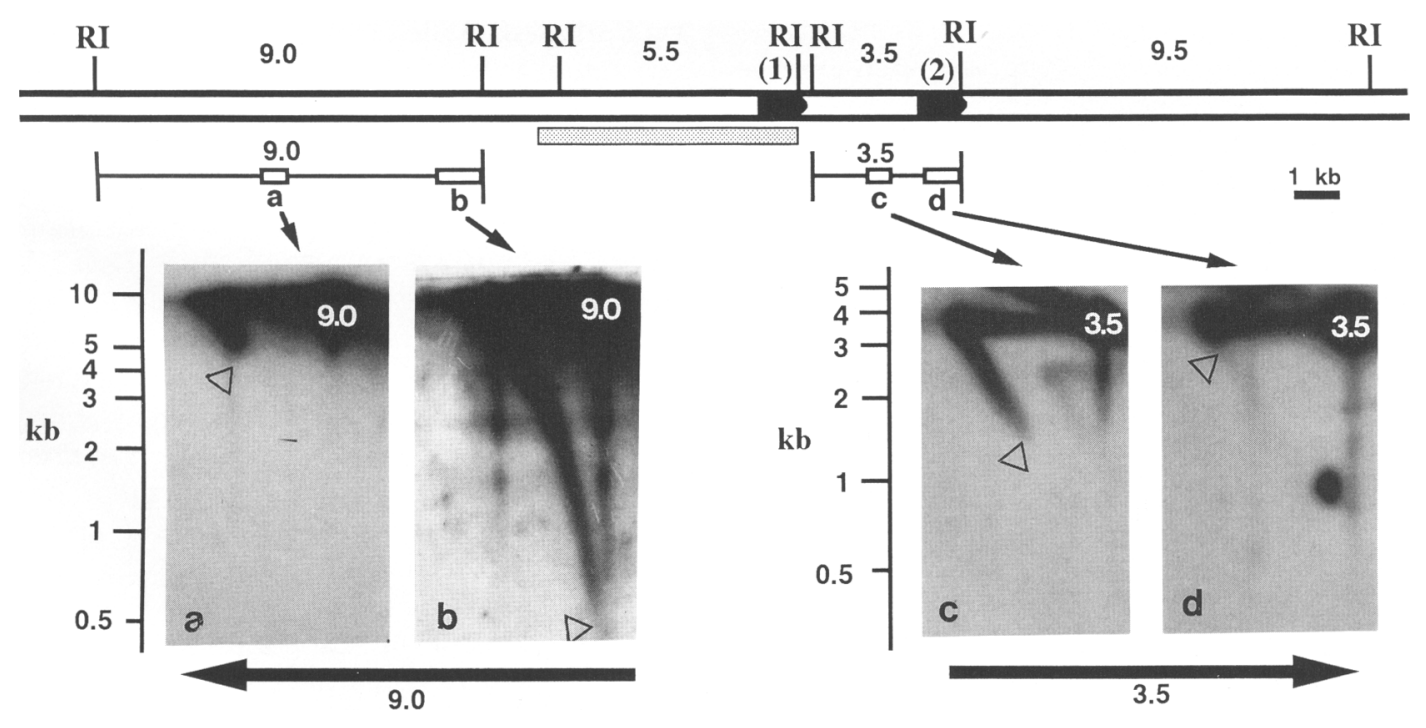

Figure 4. Replication proceeds bidirectionally outward from the origin region. About $60 \mu \mathrm{g}$ of EcoRI (RI)-digested salivary gland genomic DNA was fractionated by a BND-cellulose column. All DNA $(-3 \mu \mathrm{g})$ from the caffeine wash was run out on a neutral/ alkaline $2 \mathrm{D}$ gel $\mathrm{la} 0.35 \%$ gel run at $0.6 \mathrm{~V} / \mathrm{cm}$ for $50 \mathrm{hr}$ in the first dimension, and a $1.2 \%$ gel run at $1 \mathrm{~V} / \mathrm{cm}$ in alkaline buffer for 22 $\mathrm{hr}$ in the second dimension). The blot was hybridized sequentially with various short probes ( $a$ and $b$ from the 9.0 -kb fragment; $c$ and $d$ from the 3.5 -kb fragment). ( $\triangle$ ) The smallest nascent strands detected by the probes. Large arrows show the deduced directions of fork movement. Probe $a$ is $4.5 \mathrm{~kb}$ from the right end and $3.7 \mathrm{~kb}$ from the left end of the $9.0 \mathrm{~kb}$ fragment, and the smallest nascent strands hybridized by probe $a$ are $4.5 \mathrm{~kb}$; probe $b$ at the right end detected nascent strands of all sizes, indicating that forks move from right to left in the $9.0-\mathrm{kb}$ fragment. Probe $c$ is $1.3 \mathrm{~kb}$ from the left end of the $3.5-\mathrm{kb}$ fragment and detected nascent strands as small as 1.3 $\mathrm{kb}$; probe $d$ at the right end hybridized to only very large nascent strands, showing that forks move from left to right in the 3.5-kb fragment. The round spot near the nicked linear streak about halfway down from the $1 \times$ spot in $d$ is an artifact. 


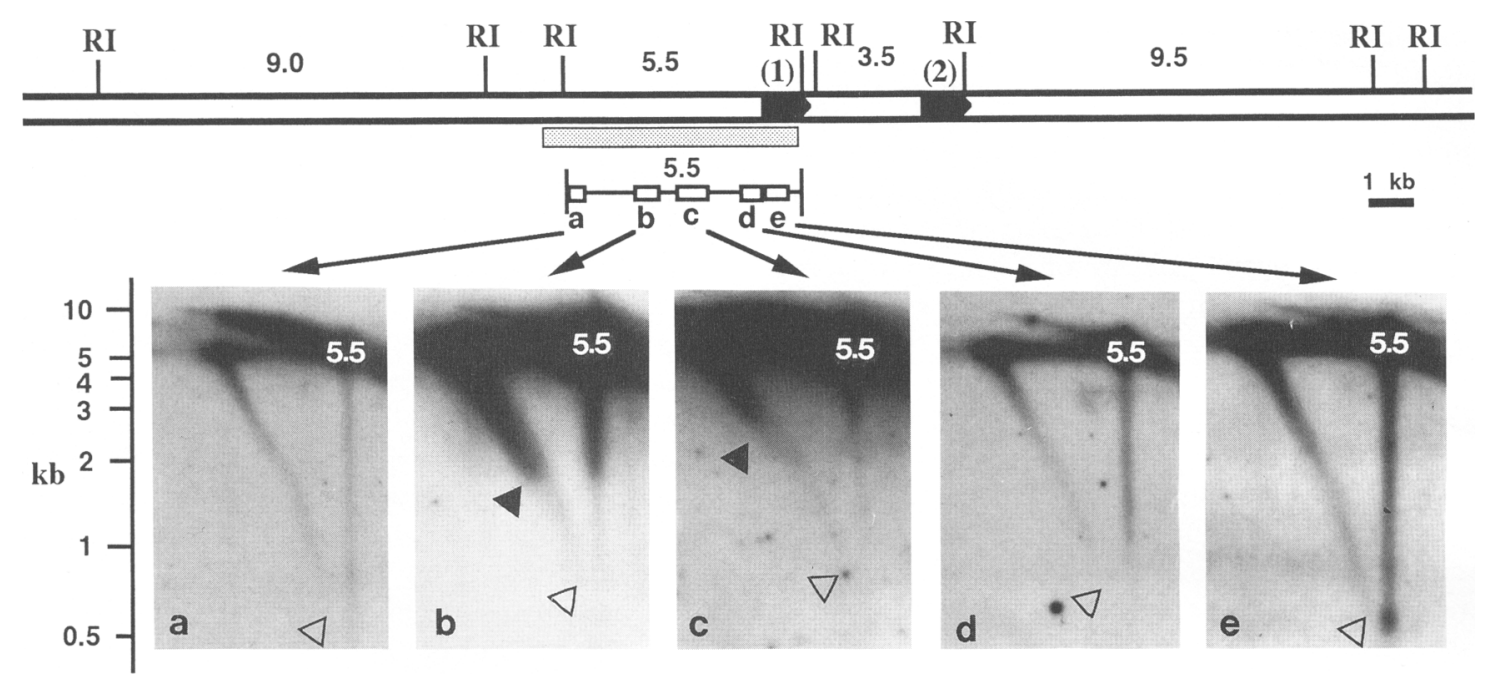

Figure 5. The neutral/alkaline $2 \mathrm{D}$ gel of EcoRI-digested DNA also shows that there are multiple initiation sites within the origin region. The same blot used in Fig. 4 (a neutral/alkaline 2D gel of EcoRI-digested DNA that was BND-cellulose enriched for replication intermediates/ was hybridized sequentially with five short probes derived from the $5.5-\mathrm{kb}$ EcoRI fragment. Each of the probes detected nascent strands as small as $0.5 \mathrm{~kb}(\Delta)$, suggesting that initiation occurs at multiple sites in this region. The transition point $(\mathbf{\Delta})$ in the nascent strand signal in $b$ or $c$ corresponds to the distance between the left end of the $5.5-\mathrm{kb}$ EcoRI fragment and the probe in each case (1.6 and $2.8 \mathrm{~kb}$, respectively), consistent with a transition from bubble-only (paler lower portion) to fork-plus-bubble (darker upper portion/ nascent strand signal.

whereas the signals above the solid triangles are contributed by both forks and bubbles.

Why is there such a strong transition in signal intensity at the solid triangle? That is, why is the lower portion of the nascent strand diagonal that results from initiation bubbles so weak? There may be several reasons. First, bubbles may be more unstable than forks and easily lost in the preparation. Second, twice as much DNA is traversed by a bubble expanding bidirectionally as a unidirectional fork moving at the same rate, thus weakening the bubble signal. Finally, the upper part of the diagonal is more compressed than the lower part for the number of molecules that they contain.

As already seen in Figure 4 for other EcoRI fragments outside the origin region, no signal was seen on the nascent strand diagonal below the position corresponding to the smallest forks (Fig. 4a,c, open triangle). Each of these probes internal to each fragment detected nascent strands of forks coming from one end of the fragment. Similarly, a probe located $1.8 \mathrm{~kb}$ from the left end of the 9.5-kb EcoRI fragment hybridized to $1.8 \mathrm{~kb}$ and larger, but not smaller, nascent strands (data not shown). If there were initiations of replication at or near the area covered by these probes, smaller nascent strands would have been detected. These results further support the conclusion from the neutral/neutral 2D gel analyses that the initiation of replication is confined to the origin region.

\section{The majority of replication initiates in $a n \sim 1-k b$} area within the origin region

To analyze the origin region in more detail, a series of neutral/alkaline 2D gel analyses were performed by use of salivary gland DNA digested with different restriction enzymes but without BND-cellulose enrichment. Because the DNA was not enriched for replication intermediates, direction of fork movement analysis reflects the forks coming from the major initiation site(s), whereas the forks from minor initiation sites produce very weak or undetectable nascent strand signals. If a restriction enzyme cut in or near the major initiation region, two restriction fragments flanking the restriction site should show fork movement in opposite directions. Therefore, the centers of bidirectionality from different digestions should localize the major initiation region.

Figure 6 shows a neutral/alkaline 2D gel experiment with HindIII-digested DNA. The size of the smallest nascent strands detected by each of the probes for the 5.4$\mathrm{kb}$ HindIII fragment increased from probe $\mathrm{c}$ to $\mathrm{b}$ to $\mathrm{a}$ (i.e., the nascent strand diagonal gets shorter), indicating that replication forks move from right to left in this fragment. In contrast, replication forks were seen to move from left to right in the $3.5-\mathrm{kb}$ HindIII fragment (Fig. $6 \mathrm{~d}-\mathrm{g}$ ). These results suggest that the HindIII site that separates the 5.4- and 3.5-kb HindIII fragments is located at or very close to the major initiation site(s).

Figure 7 shows a neutral/alkaline 2D gel experiment with PvuII-digested DNA. Replication forks were found to move from right to left in the $8.0-\mathrm{kb} P_{v u I I}$ fragment, as the size of the smallest detectable nascent strands increased from probe $\mathrm{c}$ to $\mathrm{b}$ to $\mathrm{a}$. In contrast, replication forks were seen to move from left to right in the $5.6-\mathrm{kb}$ PvuII fragment (Fig. $7 \mathrm{~d}-\mathrm{g}$ ). Four additional probes from the 5.6-kb PvuII fragment were used for hybridization (sequentially), and the results were consistent with this direction of fork movement (data not shown; see summary in Fig. 9, below). These results suggest that the 
(1) (2)

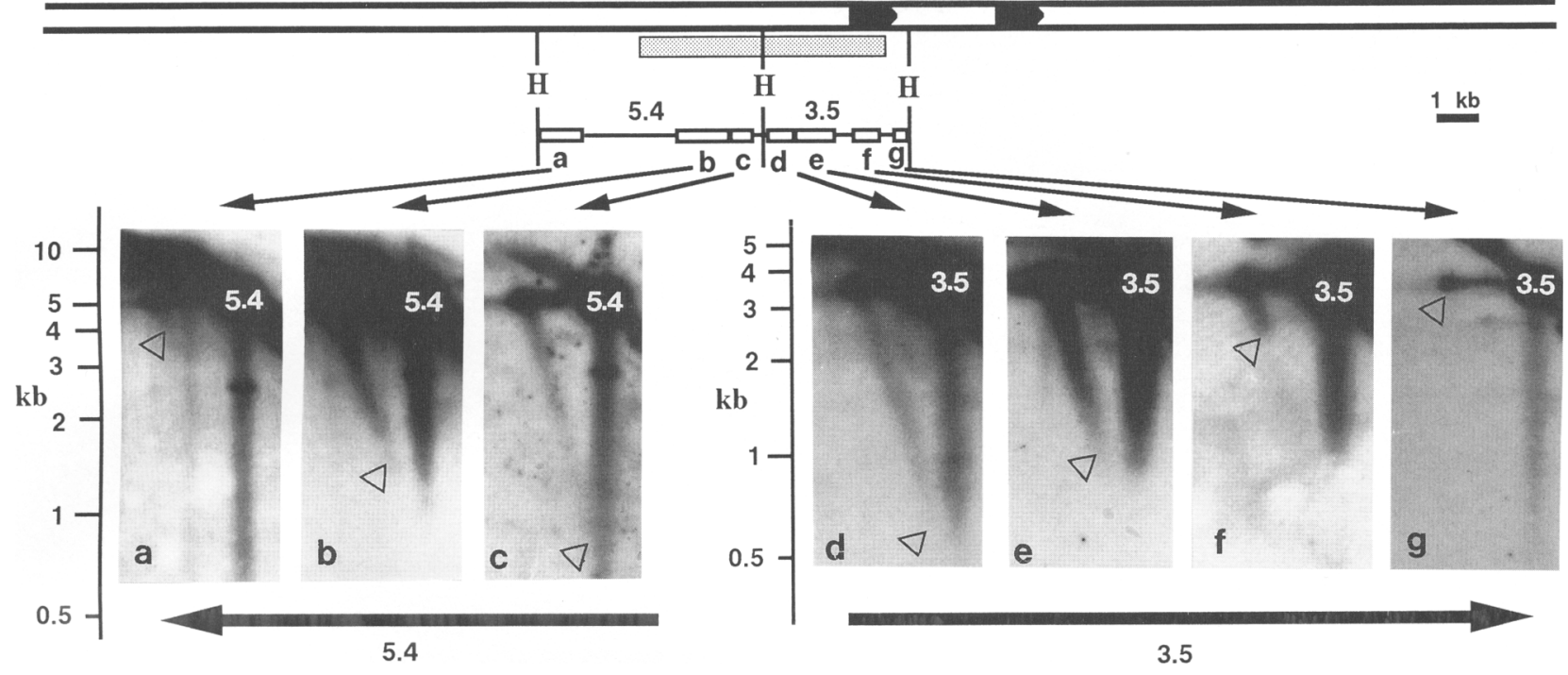

Figure 6. The HindIII site inside the origin region is at or very close to the major initiation region. About $14 \mu \mathrm{g}$ of $H$ indIII (H)-digested total salivary gland genomic DNA was run on a neutral/alkaline $2 \mathrm{D}$ gel $/ \mathrm{a} 0.35 \%$ gel run at $0.8 \mathrm{~V} / \mathrm{cm}$ for $29 \mathrm{hr}$ in the first dimension, and a $1.2 \%$ gel run at $1.5 \mathrm{~V} / \mathrm{cm}$ for $15 \mathrm{hr}$ in the second dimension). The blot was hybridized sequentially with various short probes $(a-c$ from the 5.4-kb fragment; $d-g$ from the $3.5-\mathrm{kb}$ fragment). The map positions of the probes and the sizes of the smallest nascent strands $(\Delta)$ detected by these probes are consistent with replication forks moving from right to left in the 5.4-kb fragment and the opposite in the $3.5-\mathrm{kb}$ fragment (indicated by the large arrows). This suggests that the HindIII site inside the origin region is at or very close to the major initiation region.

PvuII site flanked by the 8.0 - and $5.6-\mathrm{kb}$ fragments is also at or very close to the major initiation region. The $4.0-\mathrm{kb}$ PvuII fragment that maps farther downstream showed a direction of fork movement from left to right (data not shown; see summary in Fig. 9, below), consistent with the fragment being located downstream of the major initiation region. Results from Figures 6 and 7 suggest that a major initiation site(s) is located between the PvuII and the HindIII sites, which are $0.95 \mathrm{~kb}$ apart and reside inside the $6-\mathrm{kb}$ origin region.

Finally, to define the major initiation region at a higher resolution, the directions of fork movement were analyzed in smaller fragments with DNA cut by both PvuII and AvaII (Fig. 8). In the 1.7-kb PvuII-AvaII fragment, probes $\mathrm{c}$ and $\mathrm{d}$ at each end of the fragment each detected nascent strands of almost all sizes, although the smallest nascent strands detected were slightly larger by probe $\mathrm{d}(\sim 0.7 \mathrm{~kb})$ than by probe $\mathrm{c}(\sim 0.5 \mathrm{~kb})$, suggesting the major initiation site(s) is located within but somewhat toward the left of this fragment. The replication forks were seen to move from right to left in the upstream 4.0-kb AvaII-PvuII fragment (Fig. $8 \mathrm{a}, \mathrm{b}$ ) and from left to right in the downstream 2.2-kb AvaII-Avall fragment (Fig. 8e,f) supporting bidirectionality of replication from the major initiation site(s). These results support the conclusion that the majority of initiation occurs in the $0.95-\mathrm{kb}$ area between the PvuII site and the HindIII site that maps to the left-hand portion of the $1.7-\mathrm{kb}$ PvuII-AvaII fragment.

Figure 9 summarizes the data from Figures 6-8 and from additional hybridizations (not shown) done on these blots. The size of the smallest nascent strands detected by each probe is plotted against the map location of each probe. The centers of bidirectionality in the three experiments delimit the major initiation region to $\sim 1 \mathrm{~kb}$ (shown by the stippled circle in Fig. 9) bounded by the PvuII site and the HindIII site, which are 3.05 and $2.1 \mathrm{~kb}$, respectively, upstream of the transcriptional start site of gene II/9-1.

\section{Discussion}

Developmentally regulated DNA amplification in DNA puffs on Sciara salivary gland chromosomes provides a unique opportunity to study DNA replication. To identify the replication origin in the DNA puff II/9A locus undergoing DNA amplification in S. coprophila, we have carried out detailed origin mapping using two independent 2D gel methods (Brewer and Fangman 1987; Huberman et al. 1987). Neutral/neutral 2D gels of EcoRI- and of MscI-digested total salivary gland genomic DNA showed that initiation of replication is confined to a region of no larger than 6-kb just upstream of and including gene II/9-1 (Fig. 1). This origin region can be bisected with either PvuII or HindIII, indicating a minimum of two initiation sites (Fig. 2). A neutral/alkaline 2D gel of EcoRI-digested DNA that was BND-cellulose enriched for replication intermediates supported the results of the neutral/neutral 2D gels in two ways. First, replication forks were seen to move away from the origin region in a bidirectional manner (Fig. 4). Second, initiation of rep- 


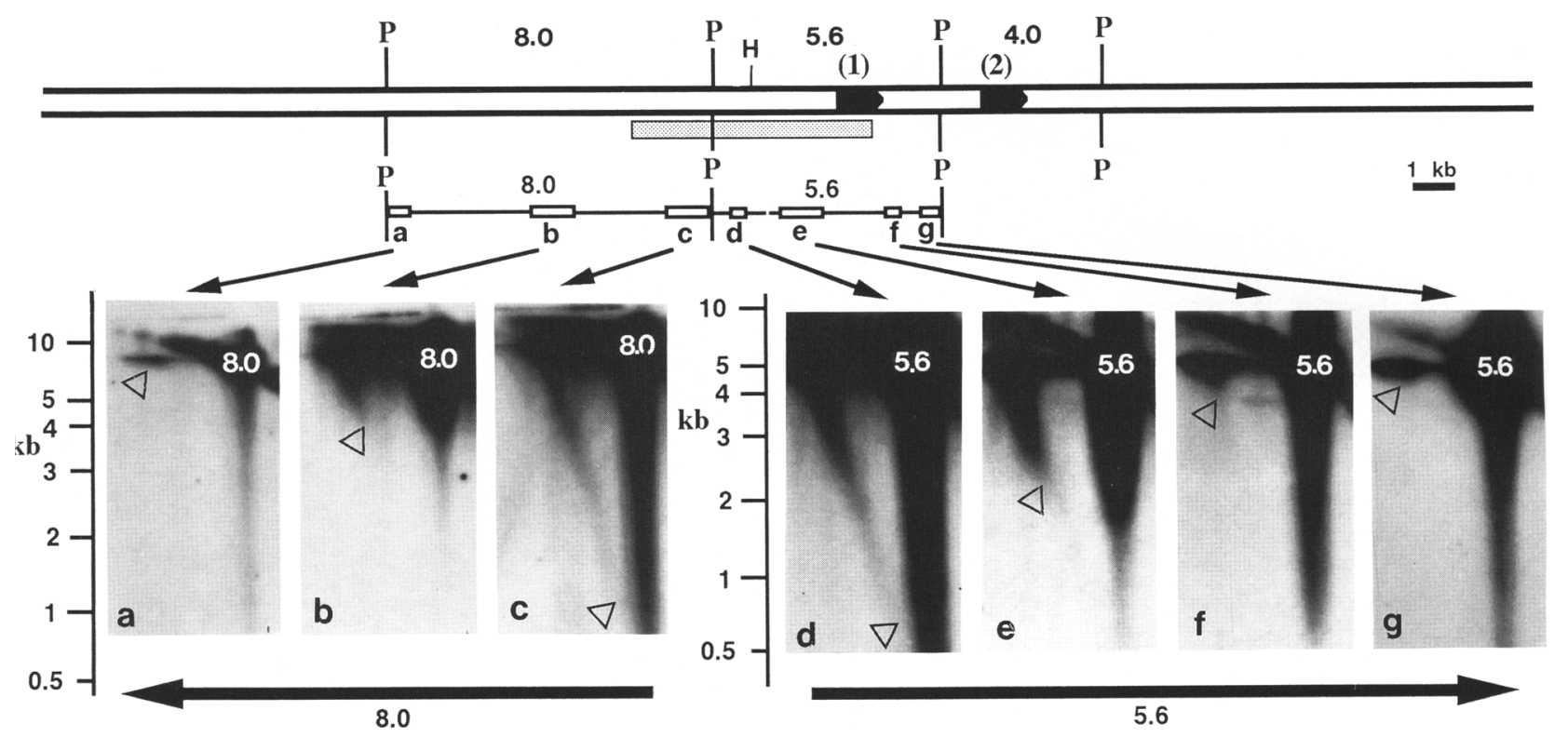

Figure 7. The PvuII site inside the origin region is also at or very close to the major initiation region. About $20 \mu \mathrm{g}$ of $P v u I I(P)$-digested total salivary gland genomic DNA was run on a neutral/alkaline $2 \mathrm{D}$ gel $/ \mathrm{a} 0.4 \%$ gel run at $1 \mathrm{~V} / \mathrm{cm}$ for $31 \mathrm{hr}$ in the first dimension, and a $1.2 \%$ gel run at $1.5 \mathrm{~V} / \mathrm{cm}$ for $17 \mathrm{hr}$ in the second dimension). The blot was hybridized sequentially with various short probes $\mid a-c$ from the $8.0-\mathrm{kb}$ fragment; $d-g$ from the $5.6-\mathrm{kb}$ fragment). The map positions of the probes and the sizes of the smallest nascent strands $(\Delta)$ detected by these probes are consistent with replication forks moving from right to left in the 8.0 -kb fragment and the opposite direction in the $5.6-\mathrm{kb}$ fragment (indicated by the large arrows). This suggests that the Pvull site inside the origin region is at or very close to the major initiation region. The HindIII site $(\mathrm{H})$ that is also at or near the major origin region (Fig. 6 ) is shown on the map for comparison.

lication was observed within (Fig. 5), but not outside (Fig. $4)$, the origin region. Further neutral/alkaline 2D gel analysis using total salivary gland genomic DNA digested with HindIII (Fig. 6), PvuII (Fig. 7), and PvuII plus AvaII (Fig. 8 ) defined within the origin region an $\sim 1-\mathrm{kb}$ area where the majority of replication initiates (Fig. 9).

Both the neutral/neutral and neutral/alkaline 2D gel methods have a resolution of $\sim 400 \mathrm{bp}$ in mapping a single fixed replication origin (as in the yeast $2 \mu$ plasmid) (Brewer and Fangman 1987; Huberman et al. 1987). Greater uncertainty is expected, however, when a complex replication origin with multiple initiation sites in a multicellular eukaryotic genome is studied. Because it is difficult to detect nascent strands smaller than $0.5 \mathrm{~kb}$ (Zhu et al. 1992 and this study) and there is uncertainty in measuring the size of small nascent strands in neutral/alkaline $2 \mathrm{D}$ gels, it is possible that the $\sim 1-\mathrm{kb}$ major initiation region we have mapped could be larger. On the other hand, our data are also consistent with, though do not prove, the possibility of a single fixed major initiation site somewhere in the $\sim 1-\mathrm{kb}$ major initiation region (see Fig. 9).

How could bubble arcs be seen in two adjacent restriction fragments in neutral/neutral 2D gels (Fig. 2) while there is an $\sim 1-\mathrm{kb}$ major initiation region? The clue to the answer comes from inspection of the bubble arcs. The continuous bubble arcs in Figure 1 suggest that very small, as well as larger, bubbles are present in the bubble arc of the 5.5-kb EcoRI (Fig. 1b) or the $4.5-\mathrm{kb}$ MscI (Fig. 1f) fragment. On the other hand, only the upper portion of the bubble arcs is obvious in the PvuII or HindIII experiment (Fig. 2). One explanation for this is that the major initiation region is near the central area of the 5.5-kb EcoRI or the 4.5-kb MscI fragment, thus giving rise to a complete set of small to large bubbles. When the origin region is bisected at the site of major initiation by either PvuII or HindIII, however, small bubbles from the major initiation would burst into forks too soon to contribute to the bubble arcs; the larger bubbles that comprise the upper portion of the bubble arcs in Figure 2 likely come from minor initiation sites. Smaller bubbles are harder to detect because the signal is spread out over a larger area of the curve. Therefore, only small bubbles derived from the major initiation site (Fig. 1) whose abundance is greater than those from minor initiation sites (Fig. 2) will be visualized.

There are several models for DNA amplification: onion-skin, rolling circle, etc. The replication fork and bubble patterns in the neutral/neutral 2D gels and bidirectionality of replication fork movement observed by the neutral/alkaline 2D gels argue against a rolling circle mechanism and are in agreement with the onion-skin model, which proposes multiple rounds of initiation from the same replication origin. The geometric doubling of DNA content in the DNA puffs measured by microspectrophotometry (Crouse and Keyl 1968) is also consistent with the onion-skin model.

DNA amplification as well as transcription in this 


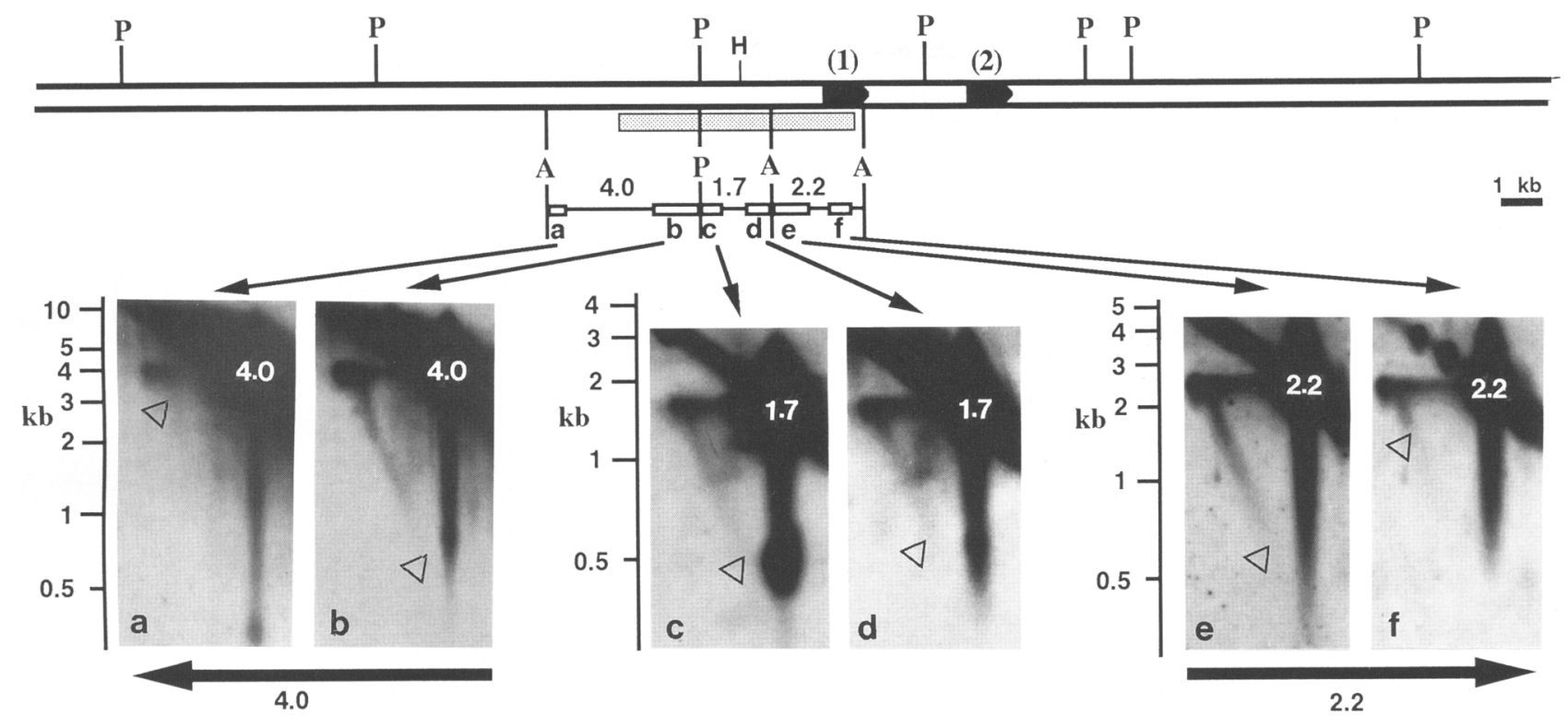

Figure 8. Neutral/alkaline 2D analysis with double-digested DNA supports the localization of the major initiation region between the PvuII site and HindIII site inside the origin region. About $20 \mu \mathrm{g}$ of total salivary gland genomic DNA digested with both PvuII (P) and $A v a I I$ (A) was nun on a neutral/alkaline $2 \mathrm{D}$ gel (a $0.6 \%$ gel run at $0.6 \mathrm{~V} / \mathrm{cm}$ for $38 \mathrm{hr}$ in the first dimension, and a $1.2 \%$ gel run at $1 \mathrm{~V} / \mathrm{cm}$ for $21 \mathrm{hr}$ in the second dimension). The blot was hybridized sequentially with various short probes ( $a$ and $b$ from the $4.0-\mathrm{kb}$ AvaII-PvuII fragment; $c$ and $d$ from the $1.7-\mathrm{kb} P v u I I-A v a I I$ fragment; $e$ and $f$ from the $2.2-\mathrm{kb}$ AvaII-AvaII fragment). In the $1.7-\mathrm{kb}$ PvuII-AvaII fragment, probe $c$ at the left end detected nascent strands as small as $\sim 0.5 \mathrm{~kb}$, and the smallest nascent strands detected by probe $d$ at the right end were slightly larger $(\sim 0.7 \mathrm{~kb})$, suggesting that the major initiation site(s) is located within but somewhat toward the left of this fragment. The replication forks were seen to move from right to left in the 4.0-kb AvaII-PvuII fragment $(a$ and $b)$ and from left to right in the 2.2-kb AvaII-AvaII fragment ( $e$ and $f)$. These results support the conclusion that the majority of initiation occurs in the area between the PvuII site and the HindIII site inside the origin region.

Sciarid DNA puff is controlled by the insect steroid hormone ecdysone (C. Liang, N. Wu, D. Alam, H.S. Smith, and S.A. Gerbi, unpubl.). During DNA puff amplification, an array of DNase I hypersensitive sites is observed within the initiation region for amplification $\sim 3 \mathrm{~kb}$ upstream of the transcription start site (F. Urnov and S.A. Gerbi, unpubl.|. These sites are not found later during development when amplification and transcription have ceased. Moreover, an ecdysone receptor response element sequence as well as three sequences with a 9 of 11 bp match to the yeast ARS consensus is found in the major initiation region (C. Liang, F. Urnov and S.A. Gerbi, unpubl.). These data suggest that the ecdysone receptor complex and other protein factors may interact with a control element(s) for DNA amplification and the major replication origin.

In conclusion, our data presented here demonstrate that replication initiates predominantly at an $\sim 1-\mathrm{kb}$ region located $\sim 2-3 \mathrm{~kb}$ upstream of gene II/9-1 during DNA amplification of the DNA puff II/9A locus. This is the first time that $2 D$ gels have been used successfully to map a replication origin to a very small region in a multicellular eukaryote. Moreover, this paper also provides the first 2D gel (neutral/alkaline) evidence that DNA replication proceeds bidirectionally in a multicellular eukaryotic system. It remains to be determined whether or not the replication origin for DNA amplification is also used for DNA replication in pre-puff stages, which would demand enormous amounts of starting material or a more sensitive technique. Comparison of replication origins for DNA replication of the genome and for DNA amplification at specific loci should shed light on the mechanism that normally allows a replication origin to fire only once per cell cycle but is overridden in DNA amplification.

\section{Materials and methods}

\section{DNA cloning}

High-molecular-weight DNA from DNA puff stage $S$. coprophila female larvae that were frozen in liquid nitrogen and ground to a powder with a mortar and pestle was isolated by lysis with $50 \mathrm{~mm}$ EDTA, $0.1 \mathrm{M}$ Tris $(\mathrm{pH} 7.5)$, and $1 \%$ SDS at $65^{\circ} \mathrm{C}$ for $20 \mathrm{~min}$, followed by the addition of potassium acetate to $1 \mathrm{M}$, incubation on ice for $20 \mathrm{~min}$, centrifugation at 10,000 rpm in an HB-4 swinging bucket rotor for $30 \mathrm{~min}$, and precipitation of DNA in the supernatant by the addition of one-half volume of isopropanol. DNA was resuspended in TE $[10 \mathrm{mM}$ Tris (pH 8.0), $1 \mathrm{~mm}$ EDTA], digested with RNase A (100 $\mu \mathrm{g} / \mathrm{ml}$ ) and $\alpha$-amylase $(25 \mu \mathrm{g} / \mathrm{ml})$ at room temperature for $1 \mathrm{hr}$, phenol extracted, and ethanol precipitated. This DNA was partially digested with Sau3A, and molecules $>25-\mathrm{kb}$ were isolated by $\mathrm{NaCl}$ or sucrose gradient centrifugation in which the gradient fractions were assayed by electrophoresis in $0.4 \%$ agarose gels. The size-selected Sciara DNA was dephosphorylated by calf 
Figure 9. The centers of bidirectionality delimit the major initiation region to $\sim 1$ $\mathrm{kb}$. The results from Figs. 6-8 lopen boxes represent probes; probe letters correspond to those in each of the diagrams) and from additional hybridization of the same filters (data not shown; probes without a letter) are summarized. The vertical position indicates the size of the smallest nascent strands detected by each probe and the horizontal position corresponds to the map position of the probe. The centers of bidirectionality in the three experiments indicate that major initiation occurs at a $\sim 1$-kb area (stippled circle) between the PvuII site and the HindIII site inside the origin region.
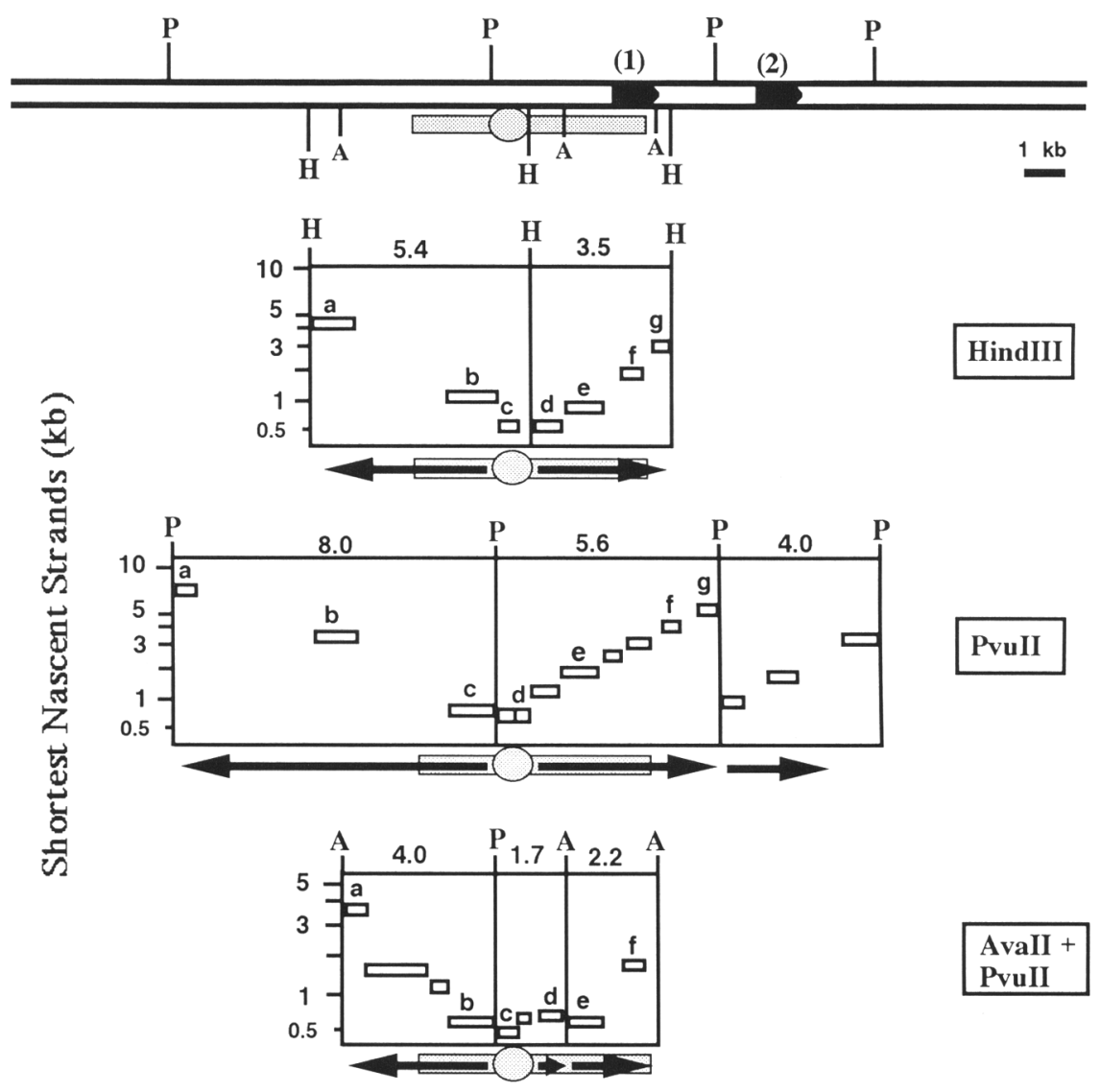

intestinal alkaline phosphatase and ligated by T4 DNA ligase in a ratio of $1: 4: 1$ for the SacI-digested cosmid, Sciara DNA, and $B s t I I-d i g e s t e d$ cosmid, respectively. The cosmid vector used was Lorist $\mathrm{B}$, which is a $5.47-\mathrm{kb}$ derivative of Loric (Little and Cross 1985), made suitable for use with the method of cosmid arm preparation described by Ish-Horowicz and Burke (1981). Briefly, Lorist B DNA was digested with SacI or BstII, dephosphorylated by calf intestinal alkaline phosphatase, and digested with BamHI, and the larger fragment for each cosmid arm (SacI arm or BstII arm/ was purified by gel electrophoresis. After ligation of the partial Sau3A-digested Sciara DNA into the BamHI site of the cosmid arms, the linear recombinant DNA was packaged for transformation of the Escherichia coli host. The 135,000 colonies were stored on master HATF nitrocellulose filters (Hanahan and Meselson 1983) after amplification (Hanahan 1985), and duplicate filters were screened with the cDNA probe pSDII/9A derived from gene II/9-1 of DNA puff II/9A (DiBartolomeis and Gerbi 1989). Subclones were constructed in Bluescript SK + or Bluescript II SK - (Stratagene). All mapping of the positive cosmid cII/9 was done by double digestion. Cosmid and subcloned DNA were purified by the alkaline lysis method (Maniatis et al. 1982).

\section{DNA preparation}

Two to three hundred pairs of salivary glands from DNA puffstage larvae were dissected out in Robert's CR-medium of 87 $\mathrm{mM} \mathrm{NaCl}, 3.2 \mathrm{mM} \mathrm{KCl}, 1.3 \mathrm{mM} \mathrm{CaCl}, 1 \mathrm{~mm} \mathrm{MgCl}$ and $10 \mathrm{mM}$ Tris- $\mathrm{HCl}$ (pH 7.3) (Robert 1971) and homogenized gently in 2.5 $\mathrm{ml}$ of $50 \mathrm{~mm}$ Tris (pH 8.0), $50 \mathrm{mM}$ EDTA, $100 \mathrm{mM} \mathrm{NaCl}$, and $1.5 \%$ Sarkosyl. After incubation with proteinase $\mathrm{K}(300 \mu \mathrm{g} / \mathrm{ml})$ at $37^{\circ} \mathrm{C}$ for $1 \mathrm{hr}, \mathrm{CsCl}$ equilibrium centrifugation was performed by the method of Huberman et al. (1987) with the following modifications: centrifugation was done in a TL-100 tabletop ultracentrifuge (Beckman) at $65,000-\mathrm{rpm}$ for $12 \mathrm{hr}$ in a TLA100.3 angle rotor, and extraction by butanol (saturated with water and $\mathrm{CsCl}$ ) preceded dialysis. Dialysis was done according to Huberman et al. (1987) if DNA was to be digested with a restriction enzyme that requires $\mathrm{Na}^{+}$and $\mathrm{Cl}^{-}$in the restriction reaction. If DNA was to be digested with an enzyme that requires $\mathrm{K}^{+}$and acetate instead, Tris- $\mathrm{HCl}$ and $\mathrm{NaCl}$ were replaced with the same concentrations of Tris-acetate and potassium acetate in the dialysis buffers. The dialyzed DNA solution was adjusted to appropriate restriction conditions and digested for 2 hr with a fivefold excess of restriction enzyme (New England Biolabs). Digestion was terminated by the addition of EDTA to $5 \mathrm{mM}$. DNA was either precipitated and redissolved in TE for $2 \mathrm{D}$ gels or adjusted to $1 \mathrm{M} \mathrm{NaCl}$ and applied to BND-cellulose (Sigma Chemical) column chromatography by the method of Dijkwel et al. (1991), but all DNA precipitations were avoided except for the isopropanol precipitation of DNA after fractionation into salt wash and caffeine wash.

\section{Electrophoresis, blotting, and hybridization}

Two-dimensional electrophoresis was carried out by the methods of Brewer and Fangman (1987) and Huberman et al. (1987), with adjustments to the gel conditions to accommodate different fragment sizes (for details, see figure legends). Pulsed-field gel-grade agarose (Boehringer Mannheim) with a higher gel strength agarose than normal agarose was used for the first dimension in most gels. All gels were run in a $4^{\circ} \mathrm{C}$ room. HindIII- 
digested $\lambda$ DNA and a $1-\mathrm{kb}$ ladder (GIBCO-BRL) were used as size markers in both dimensions.

Gels were blotted onto Biotran $\mid+$ | membrane (ICN Biohemicals) by the improved Southern transfer method recommended by the manufacturer, except that acid depurination was avoided so that small nascent strands would not be too short to be hybridized. The blotted membrane was baked at $80^{\circ} \mathrm{C}$ for $20 \mathrm{~min}$ followed by several rinses with water and a brief wash in $2 \times$ SSC.

Hybridization was carried out by one of two methods with probes labeled with both $\left[{ }^{32} \mathrm{P} \mid \mathrm{dATP}\right.$ and $\left[{ }^{32} \mathrm{P}\right] \mathrm{dCTP}$ by random priming: The first followed the manufacturer's instructions for Biotran ( + ) with increased stringency in the washes (final wash of $0.1 \times \mathrm{SSC}, 0.5 \% \mathrm{SDS}$, at $65^{\circ} \mathrm{C}$ for $30 \mathrm{~min}$, twice). The second followed the method of Church and Gilbert (1984) for hybridization, with the following modifications for washing: Washes with the second wash solution were incubated at $65^{\circ} \mathrm{C}$ with shaking for $15 \mathrm{~min}$, five times. Hybridizations and washes were carried out in lower temperatures $\left(58-62^{\circ} \mathrm{C}\right)$ when the probes were smaller than $450 \mathrm{bp}$. The filter blots were exposed to Kodak X-Omat AR films for $1-10$ days with Cronex Lighting plus intensifying screens (Du Pont) at $-70^{\circ} \mathrm{C}$. For subsequent hybridization, a previous probe was stripped off the filter either by boiling in $0.1 \times \mathrm{SSC}, 0.5 \% \mathrm{SDS}$, for $20 \mathrm{~min}$ or by incubation in $0.4 \mathrm{~N} \mathrm{NaOH}$ at room temperature with shaking for $10 \mathrm{~min}$ (twice) followed by several rinses with water and a brief wash in $2 \times$ SSC.

\section{Acknowledgments}

We are indebted to Stephen R. Mayes for construction of the Sciara genomic library in the cosmid Lorist B, and Susan M. DiBartolomeis for some of the genomic clones that we used to prepare hybridization probes. We thank Drs. Peter Little and John Sulston for advice on cosmid cloning, and Drs. Bonita Brewer and Joel Huberman for sending us protocols for yeast genomic DNA isolation and BND-cellulose chromatography, respectively, which helped us to derive our procedures. We also thank Dr. Amy Bertino for a technical suggestion concerning DNA purification, and Fyodor Urnov for computer help. The research was done in partial fulfillment for a Ph.D. degree to C. Liang from Brown University. This work was supported by a grant from the National Institutes of Health (GM 35929).

The publication costs of this article were defrayed in part by payment of page charges. This article must therefore be hereby marked "advertisement" in accordance with 18 USC section 1734 solely to indicate this fact.

\section{References}

Benard, M. and G. Pierron. 1992. Mapping of a Physarum chromosomal origin of replication tightly linked to a developmentally-regulated profilin gene. Nucleic Acids Res. 20: 3309-3315.

Bienz-Tadmor, B., H.S. Smith, and S.A. Gerbi. 1991. The promoter of DNA puff gene II/9-1 of Sciara coprophila is inducible by ecdysone in late prepupal salivary glands of Drosophila melanogaster. Cell Regul. 2: 875-888.

Bramhill, D. and A. Kornberg. 1988. A model for initiation at origins of DNA replication. Cell 54: 915-918.

Breuer, M.E. and C. Pavan. 1955. Behavior of polytene chromosomes of Rhynchosciara angelae at different stages of larval development. Chromosoma 7: 371-386.

Brewer, B.J. and W.L. Fangman. 1987. The localization of repli- cation origins on ARS plasmids in $S$. cerevisiae. Cell 51: $463-471$.

- 1991. Mapping replication origins in yeast chromosomes. BioEssays 13: 317-322.

Burhans, W.C., L.T. Vassilev, M.S. Caddle, N.H. Heintz, and M.L. DePamphilis. 1990. Identification of an origin of bidirectional DNA replication in mammalian chromosomes. Cell 62: 955-965.

Challberg, M.D. and T.J. Kelly. 1989. Animal virus DNA replication. Annu. Res. Biochem. 58: 671-717.

Church, G.M. and W. Gilbert. 1984. Genomic sequencing. Proc. Nat1. Acad. Sci. 81: 1991-1995.

Cordeiro, M. and R. Meneghini. 1973. The rate of DNA replication in the polytene chromosomes of Rhynchosciara angelae. J. Mol. Biol. 78: 261-274.

Crouse, H.V. and H.G. Keyl. 1968. Extra replication in the DNA puffs of Sciara coprophila. Chromosoma 25: 357-364.

Crouse, H. 1968. The role of ecdysone in DNA puff formation and DNA synthesis in the polytene chromosomes of Sciara coprophila. Proc. Natl. Acad. Sci. 61: 971-978.

Delidakis and F.C. Kafatos. 1989. Amplification enhancers and replication origins in the autosomal chorion gene cluster of Drosophila melanogaster. EMBO J. 8: 891-901.

DePamphilis, M.L. 1987. Replication of simian virus 40 and polyoma virus chromosomes. In Molecular aspects of papovaviruses (ed. Y. Aloni), pp. 1-40. Martinus Nijhoff Publishing, Boston, MA.

- 1993a. Origins of DNA replication in metazoan chromosomes. J. Biol. Chem. 268: 1-4.

- 1993b. Eukaryotic DNA replication: Anatomy of an origin. Annu. Rev. Biochem. (in press).

Deshpande, A. and C.S. Newlon. 1992. The ARS consensus sequence is required for chromosomal origin function in Saccharomyces cerevisiae. Mol. Cell. Biol. 12: 4305-4313.

DiBartolomeis, S.M. and S.A. Gerbi. 1989. Molecular characterization of DNA puff II/9A genes in Sciara coprophila. I. Mol. Biol. 210: 531-543.

Dijkwel, P.A. and J.L. Hamlin. 1992. Initiation of DNA replication in the dihydrofolate reductase locus is confined to the early $S$ period in $\mathrm{CHO}$ cells synchronized with the plant amino acid mimosine. Mol. Cell. Biol. 12: 3715-3722.

Dijkwel, P.A., J.P. Vaughn, and J.L. Hamlin. 1991. Mapping of replication initiation sites in mammalian genomes by twodimensional gel analysis: stabilization and enrichment of replication intermediates by isolation on the nuclear matrix. Mol. Cell Biol. 11: 3850-3859.

Dubey, D.D., L.R. Davis, S.A. Greenfeder, L.Y. Ong, J. Zhu, J.R. Broach, C.S. Newlon, and J.A. Huberman. 1991. Evidence suggesting that the ARS elements associated with silencers of the yeast mating-tape locus $H M L$ do not function as chromosomal DNA replication origins. Mol. Cell. Biol. 11: $5346-5355$.

Fangman, W.L. and B.J. Brewer. 1991. Activation of replication origin within yeast chromosomes. Annu. Rev. Cell Biol, 7: 375-402.

- 1992. A question of time: Replication origins of eukaryotic chromosomes. Cell 71: 363-366.

Ferguson, B.M., B.J. Brewer, A.E. Reynolds, and W.L. Fangman. 1991. A yeast origin of replication is activated late in $S$ phase. Cell 65: 507-515.

Ficq, A. and C. Pavan. 1957. Autoradiography of polytene chromosomes of Rhyncosciara angelae at different stages of larval development. Nature 180: 983-984.

Gabrusewycz-Garcia, N. 1964. Cytological and autoradiographic studies in Sciara coprophila salivary gland chromosomes. Chromosoma 15: 312-344. 
Gabrusewycz-Garcia, N. and R.G. Kleinfeld. 1966. A study of the nucleolar material in Sciara coprophila. J. Cell Biol. 29: 347-359.

Gahn, T.A. and C.L. Schildkraut. 1989. The Epstein-Barr virus origin of plasmid replication, oriP, contains both the initiation and termination sites of DNA replication. Cell 58: 527535.

Hanahan, D. 1985. Techniques for transformation of E. coli. in DNA cloning: A practical approach (ed. D. M. Glover), vol. I, pp. 109-135. IRL Press, Oxford, England.

Hanahan, D. and M. Meselson. 1983. Plasmid screening at high colony density. Methods Enzymol. 100: 333-342.

Heck, M.M.S. and A.C. Spradling. 1990. Multiple replication origins are used during Drosophila chorion gene amplification. J. Cell Biol. 110: 903-914.

Huberman, J.A., L.D. Spotila, K.A. Nawotka, S.M. El-Assouli, and R.D. Leslie. 1987. The in vivo replication origin of the yeast $2 \mu \mathrm{m}$ plasmid. Cell 51: 473-481.

Huberman, J.A., J. Zhu, L.R. Davis, and C.S. Newlon. 1988. Close association of a DNA replication origin and an ARS element on chromosome III of the yeast, Saccharomyces cerevisiae. Nucleic Acids Res. 14: 6373-6384.

Ish-Horowicz, D. and J.F. Burke. 1981. Rapid and efficient cosmid cloning. Nucleic Acids Res. 9: 2989-2898.

Linskens, M.H.K. and J.A. Huberman. 1988. Organization of replication of ribosomal DNA in Saccharomyces cerevisiae. Mol. Cell. Biol. 8: 4927-4935.

- 1990a. The two faces of higher eukaryotic DNA replication origins. Cell 62: 845-847.

-1990b. Ambiguities in results obtained with $2 \mathrm{D}$ gel replicon mapping techniques. Nucleic Acids Res. 18: 647-652.

Little, P.F.R. and S.H. Cross. 1985. A cosmid vector that facilitates restriction enzyme mapping. Proc. Natl. Acad. Sci. 82: 3159-3163.

Maniatis, T., E.F. Fritsch, and J. Sambrook. 1982. Molecular cloning: A laboratory manual. Cold Spring Harbor Laboratory, Cold Spring Harbor, New York.

Marahrens, Y. and B. Stillman. 1992. A yeast chromosomal origin of DNA replication defined by multiple functional elements. Science 255: 817-823.

Martin-Parras, L., P. Hernandez, M.L. Martinez-Robles, and J.B. Schvartzman. 1991. Unidirectional replication as visualized by two-dimensional agarose gel electrophoresis. J. Mol. Biol. 220: 843-853.

Rasch, E.M. 1970a. Two-wavelength cytophotometry of Sciara salivary gland chromosomes. In Introduction to quantitative cytochemistry (ed. G.L. Wied and G.F. Bahr), vol. 2, pp. 335-355. Academic Press, New York.

1970b. DNA cytophotometry of salivary gland nuclei and other tissue systems in dipteran larvae. In Introduction to quantitative cytochemistry (ed. G.L. Wied and G.F. Bahr), vol. 2, pp. 357-397. Academic Press, Inc., New York.

Rivier, D.H. and J. Rine. 1992. An origin of DNA replication and a transcription silencer require a common element. Science 256: 659-663.

Robert, M. 1971. Einfluss von ionenstärke und $\mathrm{pH}$ auf die differentielle dekondensation der nukleoproteide isolierter speicheldrüsen-zellkerne und chromosomen von Chironomus thummi. Chromosoma 36: 1-33.

Schvartzman, J.B., S. Adolph, L. Martin-Parras, and C.L. Schildkraut. 1990. Evidence that replication initiates at only some of the potential origins in each oligomeric form of bovine papillomavirus type 1 DNA. Mol. Cell. Biol. 10: 3078-3086.

Shinomiya, T. and I. Sawako. 1991. Analysis of chromosomal replicons in early embryos of Drosophila melanogaster by two-dimensional gel electrophoresis. Nucleic Acids Res.
19: 3935-3941.

Stillman, B. 1989. Initiation of eukaryotic DNA replication in vitro. Annu. Rev. Cell Biol. 5: 197-245.

Umek, R.M., M.H.K. Linskens, D.H. Kowalski, and J.A. Huberman. 1989. New beginnings in studies of eukaryotic DNA replication origins. Biochim. Biophys. Acta 1007: 1-14.

Vaughn, J.P., P.A. Dijkwel, and J.L. Hamlin. 1990. Replication initiates in a broad zone in the amplified CHO dihydrofolate reductase domain. Cell 61: 1075-1087.

Walker, S.S., A.K. Malik, and S. Eisenberg. 1991. Analysis of the interactions of functional domains of a nuclear origin of replication from Saccharomyces cerevisiae. Nucleic Acids Res. 19: 6255-6262.

Wu, N., C. Liang, S.M. DiBartolomeis, H.S. Smith, and S.A. Gerbi. 1993. Developmental progression of DNA puffs in Sciara coprophila: Amplification and transcripton. Dev. Biol. (in press).

Yang, L. and M. Botchan. 1990. Replication of bovine papillomavirus type 1 DNA initiates within an E2-responsive enhancer element. I. Virol. 64: 5903-5911.

Zhu, J., C.S. Newlon, and J.A. Huberman. 1992. Localization of a DNA replication origin and termination zone on chromosome III of Saccharomyces cerevisiae. Mol. Cell. Biol. 12: $4733-4741$. 


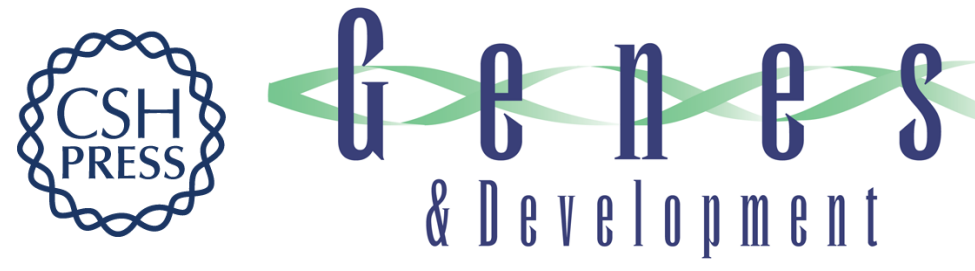

\section{Replication initiates at a confined region during DNA amplification in Sciara DNA puff II/9A.}

C Liang, J D Spitzer, H S Smith, et al.

Genes Dev. 1993, 7:

Access the most recent version at doi:10.1101/gad.7.6.1072

References This article cites 47 articles, 16 of which can be accessed free at:

http://genesdev.cshlp.org/content/7/6/1072.full.html\#ref-list-1

License

Email Alerting

Service

Receive free email alerts when new articles cite this article - sign up in the box at the top right corner of the article or click here.

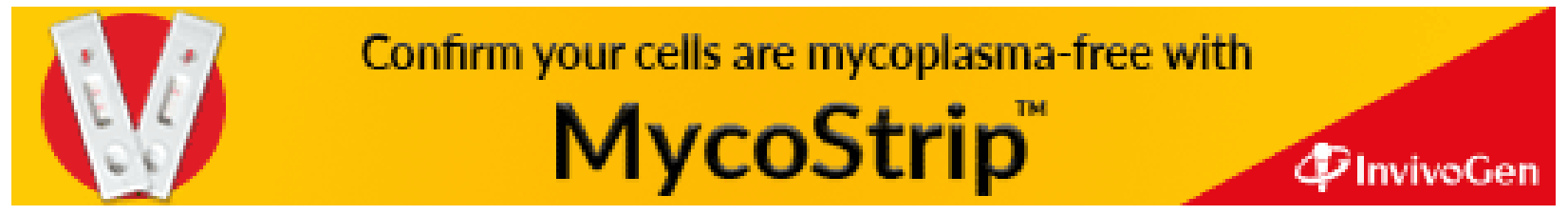

